\title{
Exploring the Perceptual and Contextual Factors Affecting Retirement Planning among Fisher Folks in the Elmina and Cape Coast Fishing Communities: A Qualitative Approach
}

\author{
Elizabeth Ewusi' ${ }^{1}$ Ronald Osei Mensah ${ }^{2 *}$ (D) Agyemang Frimpong3 ${ }^{3}$ Mary Naana Essiaw ${ }^{4}$, \\ Isaac Yeboah4, Yaw Tekyi Enchill5
}

${ }^{1}$ Institute for Distance and E-Learning, University of Education, Winneba, Ghana

${ }^{2}$ Centre for Languages and Liberal Studies, Takoradi Technical University, Takoradi, Ghana

${ }^{3}$ Ghana Institute of Management and Public Administration, Accra, Ghana

${ }^{4}$ Institute of Work, Employment and Society, University of Professional Studies, Accra, Ghana

${ }^{5}$ Library Section, Takoradi Technical University, Takoradi, Ghana

Email: *ronald.mensah@ttu.edu.gh

How to cite this paper: Ewusi, E., Mensah, R. O., Frimpong, A., Essiaw, M. N., Yeboah, I., \& Enchill, Y. T. (2021). Exploring the Perceptual and Contextual Factors Affecting Retirement Planning among Fisher Folks in the Elmina and Cape Coast Fishing Communities: A Qualitative Approach. Advances in Applied Sociology, 11, 595-617. https://doi.org/10.4236/aasoci.2021.1112051

Received: October 13, 2021

Accepted: December 10, 2021

Published: December 13, 2021

Copyright $\odot 2021$ by author(s) and Scientific Research Publishing Inc. This work is licensed under the Creative Commons Attribution-NonCommercial International License (CC BY-NC 4.0). http://creativecommons.org/licenses/by-nc/4.0/ (c) (i) (s) Open Access

\begin{abstract}
The purpose of this qualitative study was to ascertain retirement planning by fisher folks in Elmina and Cape Coast fishing communities in the Central Region of Ghana. Using qualitative research designed from a phenomenological view, 35 fisher folks were conveniently sampled for the study. These fisher folks comprised fishermen, canoe owners and fishmongers. The semi-structured interview guide was used to collect data from the participants and their responses were audio-recorded, transcribed and analyzed thematically. It was revealed from the study that most of the fisher folks regarded retirement as a period in which a person is not able to work and this is dependent on the person's level of strength, age or health condition. It also came to light that retirement planning among fisher folks is affected by factors such as the lack of labour unions or associations, seasonal conditions, high cost of operation, illegal fishing activities, extravagant spending among fishermen, lack of financial support and the mechanism of demand and supply. It is therefore recommended that an extensive public education programme on retirement planning should be implemented for fisher folks along with the fishing communities. The government, in consultation with the security agencies such as the police and the marine patrol team should come up with stringent measures to deal with individuals that engage in illegal fishing activities that pose a great threat to the livelihood of the indigenous fishermen and the fishing business in Ghana.
\end{abstract}




\section{Keywords}

Fisher Folks, Informal Sector Workers, Retirement, Retirement Planning, Social Security

\section{Introduction}

Retirement should be a period of rest from the stress and exertion of work, with most time spent with family, old school mates and, of course, in bed (MacBean, 2007). According to Costa (1998), the concept of retirement arose at the beginning of the twentieth century. This came about due to the changes in the specifics of work life. However, (Reitzes, Mutran, \& Fernandez, 1996) indicated that by the beginning of the twenty-first century, three demographic changes had significantly altered the nature and experience of retirement.

Firstly, throughout the twentieth century, there was an increase in life expectancy, which resulted in an increase in the amount of time that workers spend in retirement (U.S. Census Bureau, 2021). Secondly, since the end of World War II, there has also been increased labor force participation for women that has both increased the workforce and expanded the number of men and women experiencing retirement (Richardson, 1993). Finally, since the 1950s, there has also been a trend toward early retirement, increasingly making retirement a midlife experience and not a marker of old age (Reitzes, Mutran, \& Fernandez, 1996). Therefore, it is not surprising that retirement is institutionally recognized as a normal stage in the life cycle with its own organizations, legal infrastructure, and planned communities (Savishinsky, 1995).

Retirement, according to (Reitzes, Mutran, \& Fernandez, 1996), is now more widely recognized as a process that is influenced by pre-retirement opportunities and constraints. Hence, there is the need for individuals to pay critical attention to retirement in order to increase its opportunities and minimize the constraints. Atchley (1976) stated that the typical progression of retirement adjustment contains five stages: Honeymoon stage, which is characterized by a euphoric period where retirees relish their new freedom of time and space; disenchantment stage, which reflects the emotional let-down as people face the reality of everyday life in retirement; reorientation stage, which refers to the development of a realistic view of the social and economic opportunities; constraints of retirement stability stage, which occurs when people have achieved a certain accommodation and adjustment to retirement; and termination stage, which denotes the eventual loss of independence due to illness and disability. From this point of view, Atchley (1976) argues that retirement could become a threat to many workers who may not know what to do with their time and lives after retiring from active service.

Having spent 30 to 50 years working for money, one would normally be expected to have laid the foundation for financial stability, with pension income acting as back-up. This is not the case with many employees, especially those in the informal sector. To some extent, older workers remain in the workfield because 
they are healthy, cognitively able and want to remain engaged (Ahun, Mensah, Acheampong, Gordon, \& Turkson, 2021). Blunt cited in (Wilson \& Aggrey, 2012) stated that retirement may pose a great challenge to those workers who do not plan and also who are so attached to their work. This is manifested in terms of stress relating to changes in routine, changes in personal habits, and changes in opportunities for social interaction and for workers who take work as a central life interest, as such they are said to suffer most when it is the time to retire. Given that the attachment and commitment to work and the close personal identification with one's job can be said to be traumatic in the face of retirement, it is only logical that people plan for it (Blunt cited in Wilson \& Aggrey, 2012).

Also, in recent days, the role of the family is changing future generations. As a result, the older may not receive the care and financial support they use to expect from their families (Asamoah, 2012). He further added that in many countries, and territories, people consider it increasingly important to be self-reliant in later life. It is therefore not surprising that many workers who are approaching the age of 60 tend to be uncomfortable and unwilling to discuss issues concerning retirement. According to Jackson (2009), some of the retirees who have not well planned towards retirement and are in poverty endemic countries of the world, deal with the negative issues in retirement by adopting negative practices like drinking and regular staking of lottery, which worsens their situation and this is especially common with people in the informal sector. All the above indications show that most of our retired countrymen are poor, needy and destitute and become a burden to themselves and the country (Novy-Marx and Rauh cited in (Agbodeka, 2019)). When you are young, it is extremely challenging to think about retirement planning. Young people are busy starting careers, families, or settling in new locations, so understandably, they have the reluctance to discuss retirement planning in early life (Kwegyiriba, Mensah, Eshun, \& Agyemang, 2021).

With retirement, a variety of problems can occur. These include a decrease in roles assumed during an active work life, not being able to maintain healthy social relationships, a decrease in income, disturbances in family relationships, and not being able to maintain a healthy life (Zantinge et al., 2013). In addition, people will spend approximately one-third of their lives in retirement. So, it is very important for preparations to be made prior to retirement so that individuals and their families can have a happier and more active retirement (Johnson, 2019).

Hence, this study explores and assesses retirement planning among fisher folks. It further goes on to explore the perception of fisher folks towards retirement and the factors that affect their ability to plan for retirement.

\subsection{Statement of the Problem}

Life expectancy in Ghana has increased and the lives of the people in the Central Region are of no exception. According to (Zantinge et al., 2013), improvements in living conditions in parallel with developments in science and technology, in- 
creases in the availability of health care, development of new treatment methods, and increases in nutritional and educational resources have extended the length of life span of people worldwide. Hence, people now live for a long time in retirement. (Martin \& Whitehouse, 2008) posit that as retirement benefits continue to diminish worldwide, medical costs escalate with age and this situation is worse among informal workers in fishing communities in Ghana and for that matter Elmina and Cape Coast.

According to Bhayan (2016), fishing communities generally belong to disadvantaged groups. Comparatively, the fishermen are the people of lower economic status. Bhayan further stated that, on a whole life, fishermen are at risk and their lives have no refreshment with a very low social status. John (2015) also found that the per capita income of fisher folks generally is very low and therefore their earnings is far short of their expenditure. John (2015) added that fisher folks by nature do not save money. They spend money on the same day they get it, usually through mismanagement and over expenditure and the fisher folks of Elmina and Cape Coast fishing communities are no exception.

John (2015) further found that old aged fisher folks in Bangladesh are being provided with some amount of monthly pension by government. However, their counterpart fisher folks in Elmina and Cape Coast fishing communities do not enjoy any monthly pension from the Ghanaian government. Meanwhile, the economies of fishing communities in Ghana and for that matter the Elmina and Cape Coast fishing communities are characterized by low per capita income, low earnings, low economic and social status (John, 2015; Bhayan, 2016). Furthermore, the fishing business in itself in the Elmina and Cape Coast fishing communities in the Central Region are bedeviled with challenges such as frequent shortage and high cost of premix fuel, depleting stock, pair-trawling, unfair competition combined with high cost of doing business (Bank of Ghana, 2008). This study therefore seeks to explore retirement planning by fisher folks in Elmina and Cape Coast fishing communities in the Central Region to enhance their old age livelihood.

\subsection{Objective of the Study}

The study was guided by the following objectives:

- To explore the perception of fisher folks towards retirement;

- To identify the factors that affect retirement planning among fisher folks in the Elmina and Cape Coast fishing communities.

\subsection{Significance of the Study}

The study is intended to provide both societal and scientific significance. Societal benefits include the provision of rich information to various stakeholders such as the government, SSNIT, non-governmental and religious bodies and the general public. This study would provide an insight for government to consider the structure of the current system which fails to fully capture the workers in the in- 
formal sector. In effect providing concrete basis for the government to strengthen the policy and create awareness that will influence informal sector workers especially fisher folks to be fully enrolled on the pension scheme.

Again, findings of this study are expected to inform SSNIT to step up its sensitization programmes through all channels to fully educate the informal sector workers on the need to fully participate in the pension scheme. To the general public, they would be enlightened on the need to enroll on pension schemes which aims to better their lives when they are in their old age. Principally therefore, it is envisaged that the findings of this study would be directly applicable to and supplement the content base, timing, duration and method of delivery on the information of informal sector pension scheme to the workers in order to avoid any casualties associated with non-engagement at work as a result of old age. To non-governmental and religious bodies like Help Age Ghana, Religious leaders, social worker and many more, the findings of the study would present to them valuable information which would help them to meet the unique needs of their clients and to advise on prudent investment of surplus funds in order to ensure adequate returns on investment. It will again provide grounds for further studies and also contribute to existing literature by extending knowledge on the assessment of informal sector workers pension scheme among fisher folks.

\section{Literature Review}

\subsection{The Concept of Retirement}

Rogers (2008) said retirement is a golden time in the life of a worker, where he or she stops working and does the things that he or she had always wanted to do but had never had the time. Thus, for the first time, the individual has the leisure and freedom to travel and do other things of interest freely. Rogers (2008) posits that retirement is the act of leaving one's service either voluntary or compulsorily where such an employee has completed a specified period of service years or is removed from office by way of compulsory retirement, lay-off, dismissal (for acts of insubordination or misconduct), death, illness, disability or by voluntary withdrawal from service. To Nwachukwu (2000), retirement is a socially accepted means of withdrawing from one's occupation or business in later life to enjoy leisure, freedom or simply to cope with health problems. In his definition, Cole (2002) refers to retirement as "a period when an employee reaches the end of his working life".

Retirement was initially seen as a straight forward concept until the time where the dynamics of the growth of the population and industrialization changed the concept into a broader spectrum (Maestas, 2009). This has made it possible for retirement to be interpreted differently by people. Subjectively, retirement is seen as a self-defined notion that can be inferred differently by people. Akinade (2006) portrays it as a major dramatic life change that hauls individuals out of their life long career.

Maestas (2009) added, that for some, the term "retirement" may mean to have 
left a career or reduced the number of working hours per week from full-time to part-time status. While for others retirement means working on a voluntary basis or the state of ceasing from all work activity whether paid or unpaid. However, for most part of the world, retirement age is pegged at age 65 . Objectively, to retire simply means disengagement from business or public life. Thus, it is a time when one is no longer gainfully employed and receives a retirement pension benefit (Richardson, 1993; Atchley, 1988). (Ross \& Wills, 2009) confirmed that written research and theory on retirement shows that the definition of retirement is somewhat subtle. In spite of the subjectivity and objectivity definitions, one can agree to the fact that retirement requires reduction of activities prior to the later stages of life.

According to Jackson (2009), retirement has two main things that is certain. They include the experience it brings and the ending part of it which is death. To Jackson, the experience retirement brings is measured by well-being, joy, fulfillment, activity, misery, loneliness, pain, or limitation. This experience is unique for every individual, but limited to financial status. The second aspect shows that, regardless of when or what circumstances retirement begins with, eventually it ends in death. Thus, even though retirement may be an exciting moment for the individual eventually, death can set in and end the process.

\subsection{Retirement Planning}

Planning is a good way for individuals to take hold of their own fate with regards to retirement. Individuals who do not plan for their retirement struggle to hold on to their working identity and lifestyle, and they often retire angry, frustrated, and role-less as compared to individuals who do plan for their retirement. Hence planning towards retirement is a must for everyone in order to free one from the negative experience in retirement.

Pinterest (2019) defined planning as the process of setting goals, developing strategies, and outlining tasks and schedules to accomplish the goal. Also, Blankson (1999) added that planning is a decision making which involves the identification of problems, ranking of needs, mobilization, allocation and utilization of resources to meet those needs. Kendie (1999: p. 2), said that regardless of the levels of planning, it involves considering the existing situation in relation to the desired state which is in the future and making decisions regarding resources allocation and project types; the implementation, monitoring and evaluation of the investment programme to ensure that planned objectives are achieved. Therefore, in the researchers view, planning involves forecasting into the future and setting goals and objective to attain the target set for the future.

Planning towards retirement is the process of establishing a retirement income goal and gathering information about one's potential sources of retirement income (McKinney \& McKinney, 2005). This information about one's potential sources of retirement income is then used in determining whether or not an individual expected retirement cash flow is adequate in order to sustain the person during 
retirement. According to (McKinney \& McKinney, 2005), the tendency that people will live for several years after they have left active employment is high, hence the need for an individual to prepare adequately in order to support his or herself and their dependents. Therefore, individual's decision and commitment put in place in order to provide for income and enjoy a satisfactory lifestyle after leaving an active workforce is known as retirement planning.

Planning towards retirement requires that all workers put in place some vital measures. According to (Hershey et al., 2003), some of these measures includes seeking relevant information and advice, collecting information about retirement, establishing how much money will be needed in retirement, and discussing retirement plans with others. (Clarke-Murphy \& Gerrans, 2001) also considered the use of seminars, and the collection and use of information, as well as the consultation of others in making decisions regarding financial preparation as key measures. (McKinney \& McKinney, 2005) added that it is really about evaluating one's retirement dreams, goals, and envisioning one's financial future.

Therefore, retirement planning encompasses all the arrangements put in place by workers in order to achieve contentment, reduce inhibitions, and promote health status and leisure. Also, it enables workers close to retirement to overcome physi$\mathrm{cal}$, financial and psychological challenges when they exit from active service. Since every individual expects to retire one day from his/her work, (Kroeger \& Szinovic, 1982) shared the view that, it is useful to critically examine the planning that precedes retirement. This implies that the individual should plan for his or her retirement before he or she is due.

\subsection{Determinants of Retirement Planning}

Literature on retirement is replete with discussions on a number of factors that determine workers capacity to plan and adjust towards retirement. These determinants include: age, education, income, marital status, number of dependents and gender.

\subsubsection{Age}

In a longitudinal study to examine pre-retirement attitudes among middle-aged employees, (Crawford \& Matlow, 1972) compared the attitudes of men at two different points; at age 48 and 54. The findings indicated that positive attitudes to retirement increased within the six years between 48 and 54; $41.2 \%$ were looking forward to retirement at age 48 compared to $58.5 \%$ at age 54 . As people aged, they tend to embrace the retirement situation, thus changing the perception and beliefs they held previously about retirement. With regard to choosing a suitable age for retirement, almost one-quarter of respondents at age 48 were unable to pin-point a retirement age but at age 54 almost all respondents were able to report a suitable retirement age. The choice of an appropriate retirement age was closely related to anticipation of retirement, such that those who chose a lower age as suitable were more likely to be looking forward to retirement. The closer people get to retirement as the realities of less income and a change in 
their way of life are imminent, the less favourable the attitude towards retirement.

\subsubsection{Education}

Less educated people are most likely not to think about retirement (Lusardi, 2002); be less prepared for retirement (Warshawsky \& Ameriks, 2000); and be less likely to have basic financial knowledge (Lusardi, 2002). Even when investments have been made, evidence indicates that the level of education is a significant factor in the type of investments made. People without degrees are more likely to invest the major proportion of their retirement savings in cash; better educated people are more likely to use growth assets (Waggle \& Englis, 2000). According to (Joo \& Grabbe, 2005), those with higher educational level (college, graduate and higher) were more likely to have a savings program for retirement than those who had lower educational attainment level. According to (Petkoska \& Earl, 2009) those with higher level of education engage in health planning; another aspect of retirement planning, compared to those with lower educational level.

\subsubsection{Income}

According to Katona (1965), people in the labour force whose income are low are less optimistic about their future retirement than those people whose incomes are high. (Crawford \& Matlow, 1972) divided 1214 employees into three equal-sized groups according to annual income in a study to examine attitude towards retirement among middle-aged employees. Findings indicated that favourable attitudes to retirement increased with income; about $50 \%$ of those in low income, $62.4 \%$ of middle income and $66.9 \%$ of high-income earners were anticipating retirement. Fewer people in the low-income group were looking forward to retirement compared to the other two groups. (Donaldson, Earl, \& Muratoe, 2010) also found that higher income accounted for better retirement adjustment. Studies have found a relationship between income of people and their planning towards retirement. (Clark et al., 2003) reported that financial resources were a consideration when setting retirement income goals. Individuals with higher job earnings were more likely to set relatively high-income replacement goals compared with those with lower earnings. (Yao, Sherman, \& Catherine, 2003) found out that financial variables were driving forces for the likelihood of a household being adequately prepared for retirement.

\subsubsection{Marital Status}

The ING Retirement Research Institute (2013) in their survey on marital status, money and retirement found out that people who were married or living as married tend to demonstrate better savings behaviours and to be more financially confident than people who are single or divorced. Married individuals were more proactive retirement investors; they were most likely to be currently saving $6 \%$ or more of their salaries into a retirement fund. Single respondents were least likely to exhibit or practice "desirable" retirement planning behaviours and atti- 
tudes on knowing how to achieve retirement goals or having a formal investment plan.

(Joo \& Grabbe, 2005) however reported that there was no difference in retirement savings in terms of marital status. In a study to explore gender and marital differences in retirement plans, Szinovacz (2013) found that married women were more likely to plan stopping work at retirement. The authors explained that this may be due to reliance on their husbands' retirement income or retiring together with their husbands. Szinovacz added that this is particularly so in the Ghanaian setting where the husband is the head and bread winner of the family, so most women fail to plan towards their retirement because their husband's income will cater for them even after retirement. With regard to attitude towards retirement, married individuals were likely to have more positive attitude towards retirement (Mutran et al., 1997) while those who were never married had more negative attitudes (Turner et al., 1994). From the above studies it is quite obvious that married people engage more in retirement planning and have positive attitudes towards retirement. Reasons for these results were however not stated. Therefore, it will be interesting to find out if workers in the informal sectors such as fishing, plan differently towards retirement as a result of their marital status.

\subsubsection{Number of Dependents}

Having financial dependents can put a lot of strain on long term goals since the focus is mainly to satisfy the current financial needs. This view is supported by research showing that having dependent children is significant with regard to the setting of retirement goals (Clark et al., 2003). (Joo \& Grabbe, 2005) also reported that those who had larger household size were less likely to have a savings plan for retirement. Families with dependent children are found to be more likely to have accumulated little financial and total net worth (Lusardi, 2002). According to (Szinovacz \& DeViney, 2000), individuals who made financial contributions to children outside the household were less prone to retirement. (Turner et al., 1994) also found that number of financial dependents negatively predicted retirement attitude or confidence. This is probably so because the thought of having to take care of others with a reduced income can be very disturbing. (Kim et al., 2005) however reported there was no significant difference in retirement confidence of those who had financial dependents and those who did not have.

\subsubsection{Gender}

(Joo \& Pauwels, 2002) in their study, sort to determine factors affecting male and female workers' retirement confidence. Using a data set from the 1999 Retirement Confidence Survey (RCS) conducted by the Employee Benefit Research Institute (EBRI), 1002 (523 females and 479 males) individuals were interviewed over 22-minute telephone call. Results indicated that age, education, financial attitudes and behaviour, income and savings were factors that affected men's retirement 
confidence. Men who had higher levels of education tended to be more confident compared to those who had lower education. Younger men were more confident compared to older men. Income and having savings were positively related to retirement confidence. For women, the factors that affected their retirement confidence were risk tolerance, financial dependents, savings, financial attitudes and behaviours, income and education. Women who had positive financial attitudes and behaviours and those who had lower levels of risk aversion tended to be more confident about their retirement. Number of financial dependents was negatively associated with women's retirement confidence (Joo \& Pauwels, 2002).

\subsection{Challenges of Fishing Communities}

According to FAO (2004), the challenges that most immediately and directly threaten the sustainability of fisher folk's livelihoods in Africa are poverty, vulnerability and social exclusion. These factors apply not only to fishing communities but generally to the rural poor living in remote areas with little access to social services, infrastructure and markets.

According to UN Committee on Social, Economic, and Cultural Rights (2001), poverty is a human condition characterized by sustained or chronic deprivation of the resources, capabilities, choices, security and power necessary for the enjoyment of an adequate standard of living and other civil, cultural, economic, political and social rights. Vulnerability is understood in terms of people's exposure to risks, the sensitivity of their livelihood systems to these risks and limited assets to cope with and adapt to them (UN Committee on Social, Economic, and Cultural Rights, 2001). According to FAO (2004) while poverty and vulnerability are sometimes thought of as end results of a country's policy failures of various kinds, marginalization or social exclusion is conceived as resulting from negative social and power relations with others. The marginalized are excluded from political, social and economic opportunities enjoyed by other citizens.

However, the fisher folks in Elmina and Cape Coast (comprising fishermen, canoe owners and fishmongers) have been facing a number of challenges which threatens their business and livelihood. According to the Bank of Ghana (2008) these challenges include high premix fuel, depleting stock (sardinella and mackerel), pair trawling, unfair competition combined with higher cost of doing business is wiping many local fishermen out of the job. As part of the measures to promoting the fishing business within these coastal communities, a five-year United States International Development Project (USAID/Ghana Sustainable Fisheries Management Project) has been initiated which is aimed at contributing to the rebuild of Ghana's marine fisheries stock and catches through the adoption of responsible fishing practices (Bank of Ghana, 2008). Notwithstanding, the fishing sector in the Central Region is yet to realize the full impact of this intervention and therefore until that happens, fisher folks are not likely to make 
much gains from the business which can affect their ability to plan for their retirement.

\section{Methodology}

\subsection{Materials and Methods}

This exploratory study adopted the qualitative approach to research. This research adopted the qualitative approach, founded upon the contention that the qualitative approach enables credible investigation into people [fisher folks] in their natural settings, attempting to make sense of, or interpret, phenomena [in this case, retirement planning] in terms of the meanings they bring to them. Phenomenology which is the study of events, situations, experiences or concepts (Babbie, 2005) was the methodology employed for this research. Thus, the phenomenologist attempts to understand human behaviour through the eyes of the participants in the study. Phenomenology was used since it has the potential to penetrate deep to the human experience (retirement from fishing) and trace the essence of a phenomenon and explicate it in its original form as experienced by the individuals (fisher folks).

\subsection{Sample and Sampling Procedure}

The population for the study includes all fisher folks in Elmina and Cape Coast. By fisher folks, the researchers refer to artisanal fisher folks, canoe owners and fishmongers who work mostly at the beaches within these two fishing communities. The total population of the fisher folks could not be rightly estimated since there is no data on the actual number of people engaged in this fishing business. The justification for this population is mainly because of their relatedness to the problem identified. The total targeted population and sample for the various categories of fisher folks is presented in Table 1.

The convenience sampling technique was used to select thirty-five (35) individuals to participate in the study. The 35 participants were from both Elmina and Cape Coast fishing beaches. The selection of the thirty-five fisher folks to participate in this study was mainly influenced by, aside their availability, length of interview duration and since the majority of the participants were involved in similar job description or nature of job (e.g., fishing, smoking fish, mending nets, etc).

\subsection{Data Collection Method}

The main instrument that was prepared and used for the study was a semistructured interview guide since it gave researchers the opportunity to probe the issues further to get detailed feedback from the participants and as a result of participants' low educational background. Participants were comfortable expressing themselves in their native language (that is Fante). Besides, the semi-structured interview was employed in order to direct the focus of the interview to solicit for the right information towards the attainment of the objectives of the study. 
Table 1. Breakdown of the population and sample.

\begin{tabular}{ccc}
\hline Category & Population & Sample \\
Canoe owners & 42 & 5 \\
Fishermen & 860 & 20 \\
Fishmongers & 520 & 10 \\
Total & 1422 & 35 \\
\hline
\end{tabular}

Source: Field Data, 2020.

Specifically, focus group discussion was employed. According to (Onwuegbuzie, Dickinson, Leech, \& Zoran, 2009), focus group helps to collect data quickly, at a lower cost. Also, most of the fisher folks were mostly found in groups chatting or working at the beach. Nevertheless, we also conducted one-on-one interviews with some of the fisher folks due to their accessibility and availability, particularly the canoe owners. Some of the questions asked were "what is the perception of fisher folks towards retirement and what are the factors that affect retirement planning among fisher folks in Elmina and Cape Coast fishing communities". These were two major questions asked participants. Therefore, both individual interviews and focus group were employed as the data collection methods.

\subsection{Data Processing and Analysis}

The researchers began analyzing data following the first set of interviews to begin identifying patterns, and to facilitate subsequent data collection. We followed the data analysis and coding procedures proposed by Creswell (2006) and Esterberg (2002). In this, the specific analytical tool employed in this study was the thematic analysis. The themes that emerged from this study came directly from the participants' own meaning-making processes.

\subsection{Ethical Consideration}

The issue of retirement planning among fisher folks is a sensitive one since it has a bearing on their livelihood and wellbeing in the future. Therefore, due diligence was exercised in ensuring that ethical issues that have to do with the confidentiality of information provided by participants, informed consent of participants, voluntary participation and the secrecy of the respondents' identity was ensured during the research.

\section{Results and Discussion}

\subsection{Description of Participants}

The thirty-five fisher folks who participated in this study were drawn from the 
two main fishing communities within the Central Region of Ghana, namely Elmina and Cape Coast. These fisher folks comprised of fishermen, canoe owners and fishmongers. Though majority of the fisher folks were males, the females were equally represented in the smoking, marketing and selling of the fishes that the fishermen bring from the fishing adventure. Most of the participants indicated that they started the fishing job from childhood. Aside the account of the participants during the interview, the above assertion can also be verified from the differences in the actual age of the participants and the number of years in the business (refer to Table 1). One of them indicated that:

“...this is a kind of business where you don't choose to go into, you are either born into it or married into it" (Participant 3).

Another participant remarked:

"I grew up with my aunt who was also into the smoking of fish; so automatically, I had to help her in the business and that is how come I am in the fish smoking business" (Participant 14).

Other females who were primarily fish mongers also revealed that they got into the fishing business because it was the main occupation of their husbands. Others went into the job because they did not get any educational support and thus the only thing they could do was to trade in fish. These were supported by the accounts of some participants.

My husband was a fisherman so when we got married, I was the one who mostly take the fish that he brings from the sea to the market to sell (Participant 23).

Some women also didn't get anyone to support their education to higher levels so their only means of livelihood was to sell [smoked] fish (Participant 30).

The majority of the participants have had basic education which largely ended at the Junior High School level. Also, the majority of them were married with at least two children. Other background information of the participants is presented in Table 2.

\subsection{Results}

\section{Perception of fisher folks towards retirement}

The aim of this research question was to find out fisher folks' understanding of the term "retirement" and its application to the fishing business. The result is presented under two main emerging themes: meaning of retirement and determinants of retirement.

The term retirement is understood differently by various individuals, especially persons who work in the informal sector of the economy. The results revealed that participants had a fair knowledge on what retirement means. Some participants regarded retirement as a period in which one is not able to work. Here is what some participants said in relation to this:

"When you get old, you cannot go to the sea again so the only option is to stay home" (Participant 5). 
E. Ewusi et al.

Table 2. Background information of participants.

\begin{tabular}{|c|c|c|c|c|c|c|c|}
\hline Participant & Gender & Age & Education & Marital Status & Number of Children & Main Job & Number of Years in Fishing \\
\hline 1 & Male & 38 & JHS & Married & 3 & Fisherman & 25 \\
\hline 2 & Male & 40 & Primary & Married & 4 & Fisherman & 29 \\
\hline 1 & Male & 38 & JHS & Married & 3 & Fisherman & 25 \\
\hline 2 & Male & 40 & Primary & Married & 4 & Fisherman & 29 \\
\hline 3 & Male & 52 & JHS & Married & 6 & Canoe Owner & 39 \\
\hline 4 & Male & 35 & JHS & Married & 3 & Fisherman & 20 \\
\hline 5 & Male & 57 & JHS & Married & 5 & Canoe Owner & 40 \\
\hline 6 & Female & 39 & JHS & Married & 3 & Fishmonger & 27 \\
\hline 7 & Female & 43 & Primary & Married & 4 & Fishmonger & 29 \\
\hline 8 & Male & 20 & JHS & Single & 0 & Fisherman & 5 \\
\hline 9 & Male & 42 & JHS & Married & 4 & Fisherman & 23 \\
\hline 10 & Male & 39 & JHS & Married & 3 & Fisherman & 20 \\
\hline 11 & Male & 61 & Primary & Married & 4 & Canoe owner & 45 \\
\hline 12 & Male & 33 & JHS & Married & 2 & Fisherman & 10 \\
\hline 13 & Female & 44 & JHS & Married & 4 & Fishmonger & 25 \\
\hline 14 & Female & 39 & JHS & Married & 4 & Fishmonger & 22 \\
\hline 15 & Female & 43 & Primary & Married & 4 & Cold Store Business & 28 \\
\hline 16 & Male & 47 & JHS & Married & 3 & Fisherman & 30 \\
\hline 17 & Male & 44 & Primary & Married & 4 & Fisherman & 27 \\
\hline 18 & Male & 35 & JHS & Married & 2 & Fisherman & 15 \\
\hline 19 & Male & 52 & JHS & Married & 5 & Canoe Owner & 37 \\
\hline 20 & Male & 55 & Primary & Married & 4 & Fisherman & 30 \\
\hline 21 & Male & 35 & JHS & Married & 2 & Fisherman & 28 \\
\hline 22 & Male & 40 & JHS & Married & 5 & Fisherman & 15 \\
\hline 23 & Male & 32 & Primary & Married & 4 & Fisherman & 23 \\
\hline 24 & Male & 40 & Primary & Married & 3 & Fisherman & 18 \\
\hline 25 & Male & 40 & Primary & Married & 3 & Fisherman & 18 \\
\hline 26 & Male & 50 & Primary & Married & 2 & Fisherman & 23 \\
\hline 27 & Female & 35 & JHS & Married & 5 & Fishmonger & 12 \\
\hline 28 & Female & 40 & JHS & Married & 3 & Fishmonger & 13 \\
\hline 29 & Female & 44 & JHS & Married & 4 & Fishmonger & 20 \\
\hline 30 & Female & 29 & JHS & Married & 5 & Fishmonger & 25 \\
\hline 31 & Male & 47 & Primary & Married & 3 & Fisherman & 5 \\
\hline 32 & Male & 51 & Primary & Married & 4 & Fisherman & 15 \\
\hline 33 & Female & 40 & JHS & Married & 2 & Cold Store Business & 20 \\
\hline 34 & Male & 38 & Primary & Married & 5 & Fisherman & 12 \\
\hline 35 & Male & 49 & Primary & Married & 3 & Fisherman & 9 \\
\hline
\end{tabular}

Source: Field data, 2020. 
Other participants also saw retirement as a long-term rest for an individual after working for several years. This is how some participants described retirement:

"What I do understand by the term 'retirement' is when I have worked to a point where I cannot work anymore and so I come home to rest" (Participant 18).

Individuals go on retirement for various reasons. According to literature, these reasons include age, education, income, marital status, gender and number of children. Analysis of the responses of participants revealed that fisher folks mostly embark on retirement based on their level of strength. This means the tendency of one retiring early or late in the fishing business highly depends on how strong or weak the individual has become. One fisherman remarked:

"Our form of retirement is not like that of those in the formal sector. We have some people who are 50, 60 or 70 years and they still go for fishing. So, our form of retirement largely depends on your strength and health" (Participant 4).

He further recommended that:

"...what you have to do is that if you have a kid, you try as much as possible to send him or her to school to a level where he can also work and take care of you in future" (Participant 7).

It also emerged that one's state of health and age can influence the number of years one can go to the sea or be involved in the smoking and selling of fish, as in the case of fishmongers. The account of a fishmonger and a fisherman in support of the above finding are summarized respectively as follows:

"It [retirement] depends on your state of health. In this type of job [fish smoking] you are constantly exposed to a lot of heat and smoke which is not good for our health but we have no option. The smoke can lead to heart diseases and can even affect your sight. Also, we turn to bend most times which can also affect your waist. So, most of us normally stop or retire from this job when our health starts to deteriorate" (Participant 14).

"It depends on your age. If you are aged and get weaker, you cannot go for fishing so in that case you go on retirement. But even when you get old, like 50 to 60 years, and you can't go for fishing, there are some menial jobs you can do" (Participant 8).

\section{Factors that affect retirement planning}

When asked the factors that affect their ability to plan and prepare for retirement, many of the participants mentioned lack of association, seasonal conditions, cost of operation, illegal activities, extravagant spending, demand and supply mechanism and lack of financial support as the factors. The various factors identified have been presented as follows.

Labour unions are groups that come together to advance the course of the members. Most of these unions exist to provide social, economic and financial support to the members. According to the participants, this is not the situation with the fisher folks, especially among the fishermen and the fish mongers. Most of the participants indicated that they do not have any union or association to 
promote their interest as fishers and therefore they do not get any support or assistance when they get old and retire from the job. Some participants indicated this below:

"We don't have an association. It is only the canoe owners who have an association. As for the workers (fishermen) in the canoe, we don't have an association or group" (Participant 1).

“...in the last 20 years in this fishing business, I haven't heard of any association or group of fishermen. Everyone is on his/her own. I mostly work with my wife..." (Participant 10).

Regardless of lack of formal organization to manage the retirement preparations of the fisher folks, they have formed groups to take care of the group members. The narrative below sums it up:

"No, we don't have an association like that. However, some of the fish mongers have formed a cooperation organization, where members contribute an amount to help themselves" (Participant 7).

Furthermore, participants revealed that they are not able to get a lot of money from the fishing job to save and plan for their retirement due to environmental and seasonal conditions that are beyond their control. The fisher folks further revealed that the fishing season is unpredictable and therefore one is not guaranteed of expected returns from the business. They mostly experience this phenomenon from the month of January to April yearly. One participant equated this situation to the farming business:

“...Just like the farming business, the farmers have a period for sowing and a period for harvesting; in fishing too, we have a period where the fishes lay eggs and a period when they are fully matured to be harvested. Therefore, you go out of job when the period or season is not favourable for fishing and that can be one of the challenging times" (Participant 9).

The extract below indicates that the fishmongers are also not speared by the seasonal changes in the fishing business.

"The fishing business is a type of business where your profit or returns is not always guaranteed because there are seasons or months in which we can harvest a lot of fish and there are periods were the fishermen do not get a good catch (fishes) and this greatly affects us too. When such situations happen, we are forced to buy the fishes at a high price from the fishermen but customers are not prepared to buy them at such a price and therefore might resort to buying from the cold stores where they can get it at a relatively lower price" (Participant 14).

These situations described above further places enormous pressure on some individuals such as the canoe owners since these fishermen work for them and thus serve as their immediate employer. One participant who owns a canoe recounted his experience:

"If you are a canoe owner, these fishermen will always come to you during those difficult moments when the fishing business goes down for money to buy food, take care of their children like paying their school fees and others. This places great burden on we the canoe owners" (Participant 11). 
It is also undoubtedly clear from the interview with the fisher folks that the high cost of operating in the fishing business has a great effect on their ability to plan for retirement. Retirement planning largely depends on one's ability to save or invest his or her income but participants argued that the high cost of acquiring the canoe, maintain it, stocking it with logistics and hiring crew drains the gains of these fisher folks. One participant gave details of the cost of operation as:

"This canoe only is almost 30,000 GHC. Then the outboard motor is 12,000 GHC, the generator costs $3500 \mathrm{GHC}$ and we have 2 of it in the canoe. The bulbs we use and its cables also cost 2400 GHC. We also buy remix fuel at $600 \mathrm{GHC}$ every day or anytime we are going to the sea for fishing but if we don't travel many miles, then we can have a residue and so all we will need to do is to top the fuel. So, it is painful when you incur all these expenses and you do not get a great catch or many fishes to sell" (Participant 3).

\section{One fish monger also lamented:}

"Our expenses increase because we normally hire the ovens for the smoking of the fishes and therefore you will run into loss or you wouldn't get much money if you don't get more customers to buy your fish" (Participant 15).

Another significant factor that affects the planning for retirement among fisher folks is the illegal fishing activities of pair-trawling boats. Participants revealed that these boats prevent them from getting a good catch of fish as their big nets are able to sweep all the fishes, both matured and the fingerlings. Participants described the extent of damage cause by this illegal act:

"When we were kids, we knew that there were some leaves or farm underneath the sea that the fishes used to feed on to grow or even play within but the trawler boats have swept all these leaves or garden underneath the ocean as they conduct their illegal activities. So, most of the fishes have left our shores to find other oceans they can get food. Also, these pair trawling boats through their activities, capture both the matured fishes and fingerlings that are about to grow and also reproduce to replenish the sea. This makes it difficult to also get fishes to harvest when we go for fishing with our small canoes" (Participant 11).

The above extract depicts the worrying nature of fishers about these big vessels which are mostly operated by expatriates. This practice has continued for long and it looks like it will not end anytime soon, as the government lacks the political will to stop it. This can be inferred from the narration below:

"Though the government wants to put a stop to it but because they are able to find their way out when they are caught by the navy police, the practice still continues. We sometimes see their vessels when we go for fishing and you can't stop them because they claim that they pay taxes to the government. Again, some of the vessels that engage in these activities are owned by ministers and top government officials so they are not arrested by the marine security petrol" (Participant 2).

Other illegal activities also manifest in the form of sabotage by other fisher- 
men or fishing crew. One of the group members reported how they sabotage the activities of their colleague fishermen:

"Sometimes, other canoe owners or fishermen who think that you have very good fishermen who are able to harvest a lot of fishes anytime they go to the sea can sneak at night and cut your fishing nets so that you are not able to get a lot of fishes when you go for fishing or most of the fishes that are caught might escape" (Participant 17).

Another emergent theme of factors that affect retirement planning was the issue of extravagant spending. Most of the fisher folks are used to spending their hard end resources on unnecessary and unbudgeted expenses which serves as a big drain on their resources and their ability to save and plan towards the future. This is what some participants had to say:

"We all have different mentality, some of my colleagues can give the money they get from the fishing to their girlfriends whilst his wife and children suffer...Some don't mind spending over 1000 Ghana Cedis a day on a lady who is not his spouse, spending a lot of money on drinks for his friends and unnecessary things and so they are not available to save" (Participant 18).

Another participant also added that:

"Sometimes, the problem with most of us [fishermen] is that when we get money, we want to spend all at a go without thinking of the future. This is because, we don't know what the future holds and life is too short to worry about tomorrow. Also, we cannot guarantee being around to reap the reward. So, we are always in need of money because the little that we get, we spend it anyhow" (Participant 10).

The law of demand simply means, the higher the price of a commodity, the lesser the quantity demanded by customers and the lower the price, the higher the quantity demanded. Similarly, the activities of consumers and producers in the fishing business are influenced by this law and this have the likelihood of affecting the gains of fisher folks. Explaining how this law works in the fishing job, one fisherman said:

"Sometimes we can get a good catch but we might not get a good price for the fish. This happens because of many vessels or canoes getting a lot of fishes so the market women turn to buy them at relatively low price. Therefore, in this case you can get a lot of catch [fish] but you won't get enough money. We don't have cold stores to store them so we will be forced to sell them all at a cheaper price" (Participant 9).

One fishmonger also added:

"...there are seasons or months in which we can harvest a lot of fish and there are periods were the fishermen do not get a good catch (fishes) and this greatly affects us too. When such situations happen, we are forced to buy the fishes at a high price from the fishermen but customers are not prepared to buy them at such a price and therefore might resort to the cold stores where they can get it at a relatively lower price. We are also forced to reduce the price at which we can 
sell our fish which might be similar or lower than how much we bought them from the fishermen" (Participant 7).

She again stated:

"...some of the fish sellers from this town (Elmina) will send some of their fish to Kumasi to sell, other fish sellers from other places like Takoradi, Axim, Sempah and Moree will all send their fish to Kumasi to sell. Therefore, you will be forced to sell yours at a low price otherwise you will incur loss" (Participant 7).

The results again, revealed that fisher folks are not able to plan for their retirement because there are not attractive funding and support from financial institutions to support their business. Participants attributed this partly to their inability to provide collateral security to get loans due to the uncertain nature of the business. Therefore, participants constantly plough back their savings into the business but do not realize the expected returns. Some fishmongers have this to say about financial difficulties they face:

"Because of the uncertainties in the business, we are not encouraged to take up loans or support from these financial institutions because we might not be able to pay back. Sometimes too you would have to go and withdraw the little money you have saved to invest to go in for more fish to smoke and sell. So, you always end up not having much to save" (Participant 14).

\section{Findings}

The study revealed that the fishing business is one that involves a great deal of planning, organizing, implementation and evaluation. This notwithstanding, the business is prone to numerous challenges which have health implication for the fisher folks. It was also identified that most of the fisher folks regarded retirement as a period in which a person is not able to work and this is dependent on the person's level of strength or health. The study found out that fisher folks had no knowledge on the SSNIT Pension scheme for workers in the informal sector. In order to plan for retirement, fisher folks engage in activities such as saving in banks, investment in children's education, acquiring assets, learning additional skills and establishing other business. Furthermore, it was revealed that retirement planning among fisher folks is affected by factors such as the lack of labour unions, seasonal conditions, cost of operation, illegal fishing activities, extravagant spending among fishermen, lack of financial support and the mechanism of demand and supply.

Objective 1: To explore the perception of fisher folks towards retirement.

It was evident in the findings of the study that most of the fisher folks regarded retirement as a period in which a person is not able to work and this is dependent on the person's level of strength, age or health condition. Others also saw retirement as a long-term rest from active fishing. It is interesting to also note that the findings confirm that age is also an important factor in retirement planning since the older individuals are more conscious of the importance of 
planning for retirement as opposed to the younger generation who think they are still too young to worry about retirement

Objective 2: To identify the factors that affect retirement planning among fisher folks in the Elmina and Cape Coast fishing communities.

Furthermore, it was found out that retirement planning among fisher folks is affected by factors such as the lack of labour unions or associations, seasonal conditions, high cost of operation, illegal fishing activities, extravagant spending among fishermen, lack of financial support and the mechanism of demand and supply.

\section{Conclusion}

Based on the results of the study, the following conclusions were drawn. It is obvious that the authorities managing the Social Security and National Insurance Trust (SSNIT) are not doing much by way of publicity and creating awareness of the SSNIT Informal Sector Fund (SISF) to workers in the fishing business. This lack of knowledge on retirement planning among the fisher folks has led to the adoption of various strategies and means of planning for the future which are sometimes unsustainable in the long term. With some bits of education on how to effectively plan for retirement, fisher folks will be in a better position to prepare towards their retirement life. It can also be concluded that the activities of illegal fishing activities of pair-trawling boats do not only put the indigenous fishermen out of business but also cause great havoc to aquatic life and growth of fingerlings. This problem, if not solved, can affect the nation in terms of its inability to provide enough fishes to sell and meet the demands of the people in the country.

\section{Recommendations}

In light of the findings and conclusions of this study, we make the following recommendations:

An extensive public education programme on retirement planning, which includes both planning and counseling, should be implemented for fisher folks along with the fishing communities. The planning dimensions of these programmes should involve topics such as finances, health care, pension planning, insurance, and so forth. The counseling should be concerned with the psychological and social processes of adjustment to retirement and should include topics related to interpersonal relationships, social networks, engagement in volunteer or part-time work, and leisure. Such a programme could generate greater awareness and provide guidance and assistance at the pre-retirement and post-retirement stages.

The Government, in consultation with the security agencies such as the police and the marine petrol team, should come out with stringent measures to deal with individuals that engage in illegal fishing activities that pose a great threat to the livelihood of the indigenous fishermen and the fishing business in Ghana. 


\section{Conflicts of Interest}

The authors declare no conflicts of interest regarding the publication of this paper.

\section{References}

Agbodeka, E. (2019). Retirement Preparation of Ordained Ministers of the Presbyterian Church of Ghana. International Journal of Research and Innovation in Social Science, 3, 68-74.

https://www.rsisinternational.org/journals/ijriss/Digital-Library/volume-3-issue-3/68-7 4.pdf

Ahun, F., Mensah, R. O., Acheampong, J. W., Gordon, S. N., \& Turkson, L. (2021). Perceived Consequences of Improper Pre-Retirement Planning of Employees at the Timber Industry Development Division, Forestry Commission, Takoradi, Ghana. Dutse International Journal of Social and Economic Research, 6, 179-187.

Akinade, E. A. (2006). Towards Successful and Joyful Retirement. Olu-Akin Publishers.

Asamoah, N. (2012). Adjustment towards Retirement. Master's Thesis, Kwame Nkrumah University of Science and Technology.

Atchley, R. C. (1976). Selected Social and Psychological Differences between Men and Women in Later Life. Journal of Gerontology, 31, 204-211. https://doi.org/10.1093/geronj/31.2.204

Atchley, R. C. (1988). Social Forces and Ageing (5th ed.). Wadsworth Publishing Company.

Babbie, E. (2005). The Basics of Social Research (3rd ed.). Wadsworth.

Bank of Ghana (2008). Annual Report 2008.

Bhayan, S. I. (2016). Present Status of Socio-Economic Conditions of the Fishing Community of Maghna River, Bagladesh. Journal of Fisheries \& Livestock Production, 4, Article ID: 1000192.

Blankson, C. (1999). Positioning and Life Cycle Stages in the UK Services Industry. Ph.D. Thesis, Kingston University.

Clark, L. R., d'Ambrosio, M. B., McDermed, A. A., \& Sawant, K. (2003). Finance Education and Retirement Savings. In Sustainable Community Development: What Works, What Doesn't and Why. The Federal Reserve System.

Clarke-Murphy, M., \& Gerrans, P. (2001). Consultation and Resource Usage in Retirement Savings Decisions: Australian Evidence of Systematic Gender Differences. Financial Services Review, 10, 273-290. https://doi.org/10.1016/S1057-0810(01)00086-5

Cole, G. A. (2002). Personnel and Human Resource Management (5th ed.). Continuum Publisher.

Costa, L. D. (1998). The Evolution of Retirement [E-book]. In The Evolution of Retirement: An American Economic History, 1880-1990 (pp. 6-31). University of Chicago Press.

Crawford, L., \& Matlow, J. (1972). Some Attitudes towards Retirement among Middle-Aged Employees. Industrial Relations, 27, 616-632.

https://doi.org/10.7202/028329ar

Creswell, J. W. (2006). Qualitative Research Design: An Interactive Approach (6th ed.). SAGE Publications.

Donaldson, T., Earl, K. J., \& Muratoe, M. A. (2010). Extending the Integrated Model of 
Retirement Adjustment: Incorporating Mastery and Retirement Planning. Journal of Vocational Behavior, 77, 279-289. https://doi.org/10.1016/j.jvb.2010.03.003

Esterberg, K. G. (2002). Qualitative Methods in Social Research. McGraw-Hill.

FAO (2004). FAO Statistics. Food and Agriculture Organization.

Hershey, D. A., Mowen, J. C., \& Jacobs-Lawson, J. M. (2003). An Experimental Comparison of Retirement Planning Intervention Seminars. Educational Gerontology, 29, 339-359. https://doi.org/10.1080/713844333

ING Retirement Research Institute (2013). Marital Status, Money and Retirement.

Jackson, W. A. (2009). Retirement Policies and the Life Cycle: Current Trends and Future Prospects. Review of Political Economy, 21, 515-536. https://doi.org/10.1080/09538250903215823

John, J. A. B. (2015). The Quality of Life of Fishermen Community: A Micro Level Study. St. Michael's College, pp. 1-42.

Johnson, I. (2019, March 18). A Happy Retirement Is More than Just Money. CNBC. https://www.cnbc.com/2019/03/18/a-happy-retirement-is-more-than-just-money.html

Joo, S. H., \& Grable, J. E. (2005). Employee Education and the Likelihood of Having a Retirement Savings Program. Financial Counselling and Planning, 16, 37-49.

Joo, S. H., \& Pauwels, V. (2002). Factors Affecting Workers' Retirement Confidence: A Gender Perspective. Journal of Financial Counseling and Planning, 13. https://ssrn.com/abstract $=2442928$

Katona, G. (1965). Private Pensions and Individual Saving. University of Michigan, Survey Research Centre, Institute for Social Research.

Kendie, S. B. (1999). Do Attitudes Matter? Waste Disposal and Wetland Degradation in the Cape Coast Municipality of Ghana. Development and Project Planning Centre, University of Bradford, 2.

Kim, J., Kwon, J., \& Anderson, A. E. (2005). Factors Related to Retirement Confidence: Retirement Preparation and Workplace Financial Education. Financial Counselling and Planning, 16, 77-89.

Kroeger, C., \& Szinovic, M. (1982). Women’s Retirement. SAGE Publication.

Kwegyiriba, A., Mensah, R. O., Eshun, J., \& Agyemang, O. (2021). Perceived Consequences of Unplanned Retirement of Staff of Educational Institutions: The Case of Takoradi Technical University, Ghana. Dutse International Journal of Social and Economic Research, 6, 155-163.

Lusardi, A. (2002). Preparing for Retirement: The Importance of Planning Costs. National Tax Association Proceedings 2002, 148-154.

MacBean, E. C. (2007). Retirement Realities: Retirement Just Aren't What It Used to Be. Journal of Financial Service Professionals, 5, 40-50.

Maestas, N. (2009). Back to Work: Expectations and Realizations of Work after Retirement. Journal of Human Resources, 45, 718-748. https://doi.org/10.1353/jhr.2010.0011

Martin, J., \& Whitehouse, E. (2008). Reforming Retirement-Income Systems: Lesions from the Recent Experiences of OECD Countries. OECD Social, Employment and Migration Working Papers, OECD.

McKinney, H., \& McKinney, J. (2005). About 401K Plans: What You Need to Know.

Mutran, E. J., Reitzes, D. C., \& Fernandez, M. E. (1997). Factors that Influence Attitudes toward Retirement. Research on Aging, 19, 251-273.

https://doi.org/10.1177/0164027597193001 
Nwachukwu, C. C. (2000). Human Resources Management. Davidstones Publishers, Ltd.

Onwuegbuzie, A. J., Dickinson, W. B., Leech, N. L., \& Zoran, A. G. (2009). Toward a More Rigor in Focus Group Research: A New Framework for Collecting and Analyzing Focus Group Data. International Journal of Qualitative Methods, 8, 1-21. https://doi.org/10.1177/160940690900800301

Petkoska, J. \& Earl, J. K. (2009). Understanding the Influence of Demographic and Psychological Variables on Retirement Planning. Journal of Psychology and Aging, 24, 245-251. https://doi.org/10.1037/a0014096

Pinterest (2019). Planning the Process of Setting Goals. https://www.pinterest.com/pin/408209153710151779/

Reitzes, D. C., Mutran, E. J., \& Fernandez, M. E. (1996). Preretirement Influences on Postretirement Self-Esteem. Journal of Gerontology, 51B, S242-S249. https://doi.org/10.1093/geronb/51B.5.S242

Richardson, V. E. (1993). Retirement Counseling: A Handbook for Gerontology Practitioners. Springer.

Rogers, P. J. (2008). Using Programme Theory to Evaluate Complicated and Complex Aspects of Interventions. SAGE Journals, 14, 29-48. https://doi.org/10.1177/1356389007084674

Ross, D. G., \& Wills, L. (2009). Measuring Financial Preparation for Retirement: A New Scale Using Australian Evidence. Financial Services Review, 18, 381-399.

Savishinsky, J. (1995). The Unbearable Lightness of Retirement: Ritual and Support in a Modern Life Passage. Research on Aging, 17, 243-259.

https://doi.org/10.1177/0164027595173001

Szinovacz, M. E. (2013). Gender and Marital Status Differences in Retirement Planning. Gerontology Institute Publications.

Szinovacz, M. E., \& DeViney, S. (2000). Marital Characteristics and Retirement Decisions. Research on Aging, 22, 470-498. https://doi.org/10.1177/0164027500225002

Turner, M. J., Bailey, W. C., \& Scott, J. P. (1994). Factors Influencing Attitude toward Retirement and Retirement Planning among Midlife University Employees. Journal of Applied Gerontology, 13, 143-156. https://doi.org/10.1177/073346489401300203

U.S. Census Bureau (2021). Statistical Abstract of the United States: 1992.

Waggle, D., \& Englis, B. (2000). Asset Allocation Decisions in Retirement Accounts: An All-or-Nothing Proposition? Financial Services Review, 9, 79-92. https://doi.org/10.1016/s1057-0810(00)00057-3

Warshawsky, M., \& Ameriks, J. (2000). How Prepared are Americns for Retirement? In O. Mitchell, P. Hammond, \& A. Rappaport (Eds.), Forecasting Retirement Needs and Retirement Wealth (pp. 33-67). University of Pennsylvania Press.

Wilson, K. N., \& Aggrey, E. A. M. (2012). Retirement Planning and Counselling: Issues and Challenges for Teachers in Public Schools in the Sekondi Circuit. US-China Education Review A, 8, 755-767.

Yao, R., Sherman, D. H., \& Catherine, P. M. (2003). The Capital Accumulation Ratio as an Indicator of Retirement Adequacy. Financial Counselling and Planning, 14, 1-11.

Zantinge, E. M., van den Berg, M., Smit, H. A., \& Picavet, H. S. J. (2013). Retirement and a Healthy Lifestyle: Opportunity or Pitfall? A Narrative Review of the Literature. European Journal of Public Health, 24, 433-439. https://doi.org/10.1093/eurpub/ckt157 